\title{
Applications of Forensic Science in Private Security
}

\author{
Danielle Sapse \\ Department of Law, Police Science, and Criminal Justice Administration, John Jay College of Criminal Justice, \\ New York, USA \\ Email: dsapse@jjay.cuny.edu
}

Received October $1^{\text {st }}, 2013$; revised October 29 $9^{\text {th }}$, 2013; accepted November $26^{\text {th }}, 2013$

\begin{abstract}
Copyright (c) 2013 Danielle Sapse. This is an open access article distributed under the Creative Commons Attribution License, which permits unrestricted use, distribution, and reproduction in any medium, provided the original work is properly cited.
\end{abstract}

\begin{abstract}
Private security guards are a necessity at the present time, as a complement of the police departments in order to combat crime and terrorism. Both police forces and private security organizations are greatly helped in their work by the methods of forensic science. Forensic science applies scientific methods to the solving of crimes. These methods include fingerprinting, drug analysis, DNA (Deoxyribonucleic Acid) studies, ballistics, arson and explosive investigations, and studies of glass fragments. Fingerprinting and urine, saliva, or hair analysis for the presence of drugs are essential for the hiring of private security guards, in order to establish their suitability for the position.
\end{abstract}

Keywords: Forensic Science; Security; Fingerprints; DNA

\section{Introduction}

In modern times, issues of security have an increasingly important impact on the public awareness. Because of the rampaging crime present in our society, it is necessary to complement the police force with private security. Private security can be provided either by in-house guards or by those from contract guard agencies, or a combination.

Guard companies are of many different sizes, from some with less than 100 employees, to those with many thousands. These security corporations face many difficulties. Many of these are related to the hiring and training of the guards. There are times when the number of guards required for a situation is unpredictable. For example, if there is a strike, blackout, riot, or other emergency situation, many additional guards might be needed on very short notice. Some agencies can provide, in addition to guards, motor vehicles and other types of equipment.

Security guards come from many different backgrounds. For example, some of them are college students; some are retired police officers. Some of them are people who want to start a career in the security business, continuing to be promoted to higher positions, while others only want to work part-time to supplement another job. In the United States, men and women of any age over 18 can work as guards, and this includes many immigrants.

Applicants find out about positions in many different ways. There are ads in newspapers, referrals from other guards, and also employment agencies. The turnover of the security force varies highly ranging from a few months to several decades (Sapse, 1980).

In order to provide the best possible workforce, scientific methods are needed for the screening of prospective guards. The data obtained through the application of these methods have to be classified, selected, and stored. These processes also help decide on the appropriate person for a specific position.
Many security guard companies are interested in finding out if applicants have a criminal record because it might impact their decision to hire them. To help obtain this information, each prospective guard has to be fingerprinted. The prints are checked with the appropriate law enforcement agency. Another important issue in accepting a candidate as a guard is whether or not he or she uses illegal drugs. Fingerprinting and drug testing both pertain to the field of forensic science.

\section{Civil Law}

Besides criminal issues, security companies can be involved in civil cases (non-criminal) related to litigations. Forensic science methods are also applied to civil matters.

There are a number of characteristics that make civil law cases different from criminal law cases. Civil law cases deal with issues such as negligence, property law, contracts, and family law. In civil lawsuits one party (called, depending on the country a plaintiff, claimant or pursuer), is suing another, (called the defendant or defender). The prosecutor is not involved, and the rights related to counsel and juries are different. Also, the standard of proof to find a defendant liable (the term for guilt in civil law) is lower. The plaintiff has to prove liability only by a preponderance of the evidence (more likely than not). To prove guilt in a criminal court, the prosecutor must prove guilt beyond a reasonable doubt (that is, with a very high certainty) (Sapse, 2007).

Some civil law issues might be related to the security business. Part of the security surveillance consists in rounds by car to different locations. It is possible that a collision takes place between one of these cars and another vehicle. As in any case of collision, one of the points of interest is the identification of glass fragments. As will be shown later, an area of forensic science deals with this analysis.

An important aspect of the private security business is related to Forensic Science. Forensic science is the application of sci- 
ence to the law. It is an umbrella discipline including, besides fingerprint analysis and drug testing, many other sub-categories, such as DNA studies, toxicology, ballistics, trace evidence, and document examination. All of the above mentioned subjects are covered by the part of forensic science called criminalistics. Criminalistics is the identification, examination, and interpretation of physical evidence. It includes four categories: analysis of materials evidence, forensic chemistry, biological evidence analysis, and pattern evidence.

These subjects are studied mainly by chemical and biological methods. Such issues as chemical reactions, separation of chemicals of forensic interest by analytical procedures, and enzymatic reactions are all examined with such techniques as spectroscopy (Nuclear Magnetic Resonance, Infrared or Mass), electrophoresis, and other techniques.

Forensic science also includes areas such as forensic anthropology, pathology, entomology, odontology, psychology and psychiatry(Gaensslen, 2008).

The analysis of physical evidence found at a crime scene can be crucial to solving crime. In addition, these methods can be used to assist in the hiring of guards. They can contribute to the obtaining of information about an individual and discover this way if that individual might have a past which makes him or her inappropriate to function as a security guard.

The analysis of evidence and other forensic issues is performed in specialized laboratories all over the world. Because of its importance to society, the governments of many countries fund forensic science laboratories. These labs can have budgets ranging from less than one million dollars a year to many millions, depending on the size and the number of employees. The equipment in these laboratories can include microscopes, computers, and other analytical instruments, as well as sophisticated spectrophotometers, NMR (Nuclear Magnetic Resonance) and $\mathrm{X}$-ray equipment, lasers, and others (Gaensslen, 2008).

One of the main purposes of forensic labs is to analyze physical evidence. Physical evidence is evidence pertaining to objects found at the scene of the crime. Some examples are toolmarks, fingerprints, footprints, and glass fragments. Another type of evidence, other than physical evidence, is testimony, which is spoken evidence (that is, information conveyed by witnesses). Forensic analysis performed on physical evidence can sometimes contradict testimony that is given in court, which is not always completely reliable. Witnesses can forget important facts or even lie, but physical evidence is often more objective.

\section{Fingerprints}

One of the most precise methods to identify a person is by their fingerprints. Every person's fingerprints are differenteven those of identical twins. Also, they do not change throughout a person's life, except on very rare occasions (such as serious skin damage). Fingerprints can be identified by complicated patterns on friction ridge skin called loops, arches, and whorls. These were first defined in the book Finger Prints by Sir Francis Galton, in 1892.

In order for fingerprints to be used properly, it is important for them to be obtained, stored, and analyzed correctly. This can be done with an Automated Fingerprint Identification System (AFIS). These are systems of computers and software that can match known and unknown fingerprints. In the United States, the Integrated Automated Fingerprint Identification
System (IAFIS) is a system maintained by the Federal Bureau of Investigations and agencies can submit fingerprint information to it. The IAFIS contains the fingerprints of more than 55 million people. Fingerprints are sent not only for arrested suspects, but also for employment and other non-criminal purposes (policeone.com, 2009).

As mentioned above, candidates for security guard positions may be fingerprinted in order to determine if they have been involved in criminal activity. AFISs not only can help discover information about current crimes, but also older ones, in situations where new technologies allow for new information to be discovered. Fingerprints may be used together with other biometric systems, such as iris scans and retinal scans, in order to obtain more accurate results.

Fingerprints can be detected when chemical substances are secreted from the pores within the ridges on fingertips. These chemicals are deposited in a pattern that reflects the pattern on the friction skin (Sapse, 2007).

One very important chemical method of identifying fingerprints is the use of a chemical called Ninhydrin. This chemical reacts with amino acids found in the perspiration in fingerprints and produces a purple-bluish substance.

\section{DNA}

Another part of forensic science research, due to the fact that it permits a very precise identification of individuals, is DNA. DNA (Deoxyribonucleic Acid) is a chemical found in the nucleus of cells, and plays a fundamental rule in heredity and in many biological phenomena.

In the security business, DNA analysis, even though not applied routinely in the hiring of guards, might be applied for identification of suspects at an eventual scene of a crime. It can also determine the presence of a guard at a certain scene.

In the United States, the FBI (Federal Bureau of Investigations) also has a national DNA database called CODIS (Combined DNA Indexing System). DNA databases match DNA evidence found at a crime scene with known DNA records. DNA can identify a person with an accuracy of more than 99.9\%. Other countries also have national databases, such as the UK National Criminal Intelligence DNA Database and the FNAEG in France.

There are many examples of the usefulness of DNA in the solving of crimes. For instance, in 2012, a security guard was shot and killed while working at an apartment complex. At first, it was not clear who committed the crime. Surveillance cameras showed a man on a bicycle near the scene of the crime, who was suspected to be the killer. The security guard company for which the victim worked offered a $\$ 10,000$ reward for information leading to an arrest. A few days later, an arrest was made of a sixteen-year old who was then charged with the murder, as well as armed robberies and other crimes. This was a situation in which DNA could be used to identify the criminal. A bicycle was left at the scene of the crime and was analyzed for DNA; the DNA was shown to match the suspected murderer (Ingles, 2012).

There was another case in which a security guard was accused of the murder of many women, apparently mostly prostitutes, over several years. He was charged with murder, sexual assault, and kidnapping.

DNA was gathered from the bodies of two of the victims, one that was found in 2002 and the other that was found more 
recently. The DNA was found to be from the same person. The second victim's body was found near a site where security guards worked. The police showed the surviving victims pictures of guards from the firm, and they identified the suspect. The guards, including the suspect, voluntarily gave DNA samples and this way, a match was found with the suspect (Pinkerton, 2011).

\section{Glass}

Another type of important scientific evidence is glass. As shown before, glass identification, for instance, at a scene of a car collision can prove important.

Glass has properties that can identify it, such as density (which can be determined from the mass and volume) and refractive index. The refractive index is a number which describes the way the light passes through a substance, such as glass.

Discovering the elements in glass is another way to distinguish one sample of glass from another. Glass is made from sand, so the composition of the glass will depend on the composition of the sand. Sand from different places will contain somewhat different substances, and this will create a difference in the glass. As far as the chemical composition is concerned, glass contains several different combinations of elements. Some of the elements present in glass are silicon, calcium, and oxygen, as well as many others in various amounts (Gaensslen, 2008).

\section{Weapons and Ballistics}

Weapons are a part of many crimes, so it is useful to be able to recognize which ones were used. The determination of who fired a weapon can distinguish a criminal from an innocent person.

To obtain such information, gun residues have to be analyzed. Residue (made of gunpowder, primer, metals from the bullet, and dirt) can be found on the suspect's hands, and also on various surfaces. The pattern of residue on a surface can help to show the distance from which the gun was shot. Sometimes the pattern can be seen easily, but often, it has to be chemically enhanced to be seen.

Ballistics is the study of the trajectory of the bullet. This way, the position of the suspect and the victim can be discovered. Some of this information can come from the entry and exit wounds on the victim's body.

\section{Arson and Explosives}

A category of crimes particularly subjected to investigation by security forces together with the fire department is related to arson and explosives.

Arson is the burning of a structure. Traditionally, it was the burning of a home belonging to another person, but now, it can be the burning of any type of structure, including one's own house, as long as it is intentional; that is, not an accident. There are a number of reasons why people commit this crime. It could be for insurance reasons, to cover up another crime, or simply to damage property (Scheb, 2007).

The process of burning is called combustion. It is an oxidation reaction that occurs when oxygen combines with carbon to form carbon dioxide, and the reaction gives off heat(Gaensslen, 2008).
When there is a fire, it is important to determine whether it was caused by arson or was an accident or natural disaster. There are a number of ways in which the cause of a fire can be discovered.

Investigators will try to find out the point of origin, that is, the location from which the fire started. If there are several points of origin this may indicate that the fire was set intentionally. One way of finding this out is by examining the burn pattern. For instance, if the pattern is a cone shape, the point of the cone could be the point of origin.

Also, burn patterns can indicate the way that a fire was started. For example, wildfires often move in a certain type of pattern and spread outward and move faster uphill. These patterns can also indicate if the fire was started with gasoline or another type of fuel. Also, certain types of burned trees and grass can be indicative of a naturally occurring fire.

There are many incidents of crime that involve explosives: These crimes can be terrorist acts or crimes targeted at an individual, such as a bomb placed under a car. Governments at all levels: local, state, and federal, have agencies that address themselves to this type of crime.

Explosions require a small amount of energy to start and a large amount of heat is produced. It is clear that security guards should be very vigilant in preventing arson and explosions. The guards should be attentive to any unusual noises or odors that could indicate a crime of arson or bombing about to be committed.

\section{Drugs}

Security guards who take drugs can be a serious problem. Guards may have weapons or use vehicles and being under the influence can affect them and cause grave consequences. Also, guards sometimes have to make instant decisions and so their judgment should not be impaired by drugs.

Because of this, many security guard companies perform drug tests on prospective employees. Some companies test routinely, while others do so only if the client requests it and pays for it.

There are different drugs that can be tested for, including cocaine, marijuana, opiates, methamphetamines, amphetamines, phencyclidine (PCP), benzodiazepines, barbiturates, methadone, tricyclic antidepressants, and others. There are several ways to test a person for drugs. Three of the most common are the testing of urine, saliva, or hair. Each one has advantages and disadvantages. Urine tests give instant results and can test for many different types of drugs; however there is a possibility of tampering. Saliva testing has the advantage of being convenient and not invasive, and it can detect recent drug use. The disadvantages are that the results depend on the individual rate of saliva production and the nature of the drug used. Also, it can only detect the recent use of drugs. Testing of hair is the most effective and convenient method, however it requires a longer waiting period and can be more costly. Also, it may not detect very recent use of drugs (drugtestingnetwork.com).

\section{Conclusion}

Since the security business is strongly involved in preventing crimes and if crimes do occur, in participating in their solving, knowledge about the forensic science methods is a valuable asset for the security workforce. 


\section{SAPSE}

\section{REFERENCES}

Drug testing network, inc. http://drugtestingnetwork.com

Gaensslen, R. E., Harris, H. A., \& Lee, H. (2008). Introduction to forensic science and criminalistics. New York, NY: McGraw-Hill Companies, Inc.

IAFIS (2009). All about integrated automated fingerprint identification systems.

http://www.policeone.com/police-products/investigation/articles/180 2754-All-about-Integrated-Fingerprint-Identification-System-IAFIS/

Ingles, J. (2012). 16-year-old boy arrested for security officer murder, ATM armed robberies. ABC Action News.

http://www.abcactionnews.com/dpp/news/region_tampa/teen-arreste d-for-security-officer-murder-atm-armed-robberies

Pinkerton, J. (2011). Guard may be linked to killings of 15 prostitutes. HoustonChronicle.

http://www.chron.com/news/houston-texas/article/security-guard-call ed-predator-charged-in-2227974.php

Sapse, A. M., Schenkin, P., \& Sapse, M. (1980). Computer applications in the private security business. New York, NY: Praeger.

Sapse, D. (2007). Legal aspects of forensics. New York, NY: Chelsea House.

Scheb, J. M. \& Scheb, J.M. II. (2012). Criminal law (6th ed.). Belmont, CA: Wadsworth. 